\title{
Complete chemical analyses of metamorphic hornblendes: implications for normalizations, calculated $\mathrm{H}_{2} \mathrm{O}$ activities, and thermobarometry*
}

\author{
Michael A. Cosca ${ }^{1, * *}$, Eric J. Essene ${ }^{1}$, and John R. Bowman ${ }^{2}$ \\ ${ }^{1}$ Department of Geological Sciences, University of Michigan, Ann Arbor, MI 48109-1063, USA \\ ${ }^{2}$ Department of Geology and Geophysics, University of Utah, Salt Lake City, UT 84112, USA \\ Received January 18, 1990 / Accepted March 28, 1991
}

\begin{abstract}
Twenty-two hornblendes separated from amphibolites and granulites of the Grenville Orogen of Ontario have been quantitatively analyzed for major and minor elements by electron microprobe, for $\mathrm{FeO} / \mathrm{Fe}_{2} \mathrm{O}_{3}$ by wet chemistry, and for $\mathrm{H}_{2} \mathrm{O}$ by manometric measurement as $\mathrm{H}_{2}$. Hornblende formulae were calculated on the basis of $24 \mathrm{O}+\mathrm{OH}+\mathrm{Cl}+\mathrm{F}$. Most samples are magnesio-hornblendes, ferroan pargasitic hornblendes and ferroan hastingsitic hornblendes, with weight fractions of $\mathrm{Fe}^{3+} /\left(\mathrm{Fe}^{2+}+\mathrm{Fe}^{3+}\right)$ ranging from 0.15 to 0.50 . An oxy-amphibole component of $0-25 \mathrm{~mol} \%$, with an average value of $17 \mathrm{~mol} \%$, is obtained for these complete analyses. When compared with structural formulae determined solely from microprobe data, normalization based on $13=\mathrm{Si}+\mathrm{Ti}+\mathrm{Al}+\mathrm{Fe}+\mathrm{Mn}+\mathrm{Mg}$ cations provides the best approximation to hornblende formulae calculated from the complete analyses. Less satisfactory agreement is obtained from a normalization scheme based on $15=\mathrm{Si}+\mathrm{Ti}+\mathrm{Al}+\mathrm{Fe}+\mathrm{Mn}+\mathrm{Mg}+\mathrm{Ca}$, while worst agreement is obtained from normalization to 23 oxygens assuming all $\mathrm{Fe}$ is $\mathrm{Fe}^{2+}$. No normalization scheme based on microprobe data alone consistently replicates the measured $\mathrm{FeO}, \mathrm{Fe}_{2} \mathrm{O}_{3}$, and $\mathrm{H}_{2} \mathrm{O}$; accurate determination of these values requires complete chemical analyses. Ionic solution models previously have been proposed to evaluate the activity of $\mathrm{Ca}_{2} \mathrm{Mg}_{5} \mathrm{Si}_{8}$ $\mathrm{O}_{22}(\mathrm{OH})_{2}\left(a_{\text {Trem }}\right)$ in hornblende for use in equilibria that constrain the activity of $\mathrm{H}_{2} \mathrm{O}\left(a_{\mathrm{H}_{2} \mathrm{O}}\right)$ in igneous and metamorphic rocks. Application of ionic models to typical hornblendes produces low $a_{\text {Trem }}$ (usually $<0.01$ ), consequently yielding extremely low $a_{\mathrm{H}_{2} \mathrm{O}}$. If an oxy-amphibole component is present, the calculated $a_{\text {Trem }}$ and $\mathrm{H}_{2} \mathrm{O}$ is further reduced. An oxy-amphibole component of $25 \%$ reduces the calculated $\mathrm{H}_{2} \mathrm{O}$ activity and that of any hydroxyl-amphibole component by $50 \%$ below that
\end{abstract}

Offprint requests to: M.A. Cosca

* Contribution No. 478 from the Mineralogical Laboratory, University of Michigan

** Current address: Université de Lausanne, Institut de Minéralogie et Petrographie BFSH2, CH-1015 Lausanne, Switzerland calculated with simplified assumptions regarding $X_{\mathrm{OH}}$ in the hydroxyl site (i.e., $X_{\mathrm{OH}}=1$, or $X_{\mathrm{OH}}=1-X_{\mathrm{Cl}}-X_{\mathbf{F}}$ ). Thus, methods of amphibole normalizations appear to have a substantial effect on calculated amphibole and $\mathrm{H}_{2} \mathrm{O}$ activites. Before quantitative hornblende thermobarometry can be calibrated and applied, the amounts of $\mathrm{FeO}, \mathrm{Fe}_{2} \mathrm{O}_{3}$ and $\mathrm{H}_{2} \mathrm{O}$ must be measured in order to fully characterize hornblende solid solutions.

\section{Introduction}

Hornblende is commonly present in many high-grade metamorphic rocks, including mafic to felsic granulites which are generally thought to have equilibrated under conditions of $P_{\mathrm{H}, \mathrm{O}}<P_{\text {total }}$ (e.g., Bohlen et al. 1980; Valley et al. 1983, 1990; Edwards and Essene 1988; Lamb and Valley 1988). The composition of hornblende may ultimately be used to constrain the metamorphic $P_{\mathrm{H}_{2} \mathrm{O}}$ if accurate formulae and activity-composition $(a-X)$ relations are available for hornblende solid solutions. While realistic $a-X$ models for complex minerals such as hornblende have yet to be developed, it is possible to determine accurate hornblende formulae if complete chemical analyses are available. However, most petrologic studies that include hornblende in calculations of phase equilibria are based on hornblende formulae derived from incomplete electron-microprobe analyses.

Because hornblendes usually contain some ferric iron, as well as ferrous iron and hydroxyl ion, accurate hornblende formulae require accurate measurements or reliable estimates of these ions (Leake 1968). Before electron-microprobe analyses became commonplace, hornblende compositions were determined by a variety of wet chemical techniques on mineral separates that usually included measurement of $\mathrm{SiO}_{2}, \mathrm{TiO}_{2}, \mathrm{Al}_{2} \mathrm{O}_{3}, \mathrm{Fe}_{2} \mathrm{O}_{3}$, $\mathrm{FeO}, \mathrm{MnO}, \mathrm{MgO}, \mathrm{CaO}, \mathrm{Na}_{2} \mathrm{O}, \mathrm{K}_{2} \mathrm{O}$ and $\mathrm{H}_{2} \mathrm{O}$, in addition to measurements of $\mathrm{Cl}_{2}$ and $\mathrm{F}_{2}$ (e.g., Leake 1968). Such analyses of hornblende usually accounted for the significant cations and anions, and a formula was calcu- 
lated on the basis of $24=\mathrm{O}+\mathrm{OH}+\mathrm{Cl}+\mathrm{F}$ (e.g., Deer et al. 1963). With the advent of modern electron microprobes, wet chemical analyses of mineral separates have become exceedingly rare, as data can be obtained rapidly with much less effort; nearly all recent studies report hornblende formulae estimated from electron-microprobe data alone. A serious shortcoming of the electron microprobe when used to analyze complex $\mathrm{OH}-$ and iron-bearing minerals, such as hornblende, is its inability to measure $\mathrm{H}_{2} \mathrm{O}$ and to discern $\mathrm{Fe}^{2+}$ from $\mathrm{Fe}^{3+}$. Nevertheless, most electron-microprobe analyses of hornblende continue to be published with structural formulae reported on the basis of 23 oxygens assuming that all $\mathrm{Fe}$ is $\mathrm{Fe}^{2+}$ (for careful discussions of the limitations of this method, cf. Stout 1972; Robinson et al. 1982).

In a recent experimental study, Clowe et al. (1988) measured the $\mathrm{Fe}_{2} \mathrm{O}_{3} / \mathrm{FeO}$ ratio of natural amphiboles annealed at $750^{\circ} \mathrm{C}$ in air and $650^{\circ} \mathrm{C}$ at $1 \mathrm{kbar}$, showing that this ratio varies with the $f_{\mathrm{O}_{2}}$ of the experiment and is experimentally reversible. The well known reaction is:

\section{$2 \mathrm{Fe}^{2+}(\mathrm{OH})_{2}$ (in amphibole) $=$$$
2 \mathrm{Fe}^{3+} \mathrm{O}(\mathrm{OH}) \text { (in amphibole) }+\mathrm{H}_{2} \text {, }
$$

which is a measure of $f_{\mathrm{O}_{2}}$ only at fixed $\mathrm{f}_{\mathrm{H}_{2} \mathrm{O}}$. Although Clowe et al. (1988) did not determine directly the $\mathrm{H}_{2} \mathrm{O}$ contents of their amphiboles, variation in $\mathrm{Fe}_{2} \mathrm{O}_{3} / \mathrm{FeO}$ is related to concomitant variation in $\mathrm{O} / \mathrm{OH}$ by the above reaction. However, the $\mathrm{OH}$ estimated in their amphiboles is likely to have systematic errors as the starting materials were assumed to carry stoichiometric amounts of $\mathrm{OH}$, and the amounts of $\mathrm{OH}$ in the run products were calculated relative to the assumed $\mathrm{OH}$ in the starting materials. As yet the $\mathrm{Fe}_{2} \mathrm{O}_{3} / \mathrm{FeO}$ ratio in natural amphiboles cannot be related to the $f_{\mathrm{H}_{2}} / T$ at the time of last equilibration without a direct determination of $\mathrm{O} / \mathrm{OH}$ and a comprehensive mixing model.

We report complete chemical analyses of 22 metamorphic hornblendes that were separated from amphibolites and tonalitic gneisses. The hornblende formulae determined on the basis of $24=\mathrm{O}+\mathrm{OH}+\mathrm{Cl}+\mathrm{F}$ are compared to formulae calculated using electron-microprobe data alone. The common method of normalizing microprobe data to 23 oxygens while assuming that all $\mathrm{Fe}$ is $\mathrm{Fe}^{2+}$ is shown to have large systematic errors, and more reliable cation normalization schemes are suggested. Moreover, based on the inferred $\mathrm{OH}, \mathrm{F}, \mathrm{Cl}$, and $\mathrm{O}$ occupancies in the $\mathrm{OH}$ sites of the hornblendes, we conclude that $\mathrm{H}_{2} \mathrm{O}$ activities calculated from hornblende equilibria may be grossly in error even if the accuracies of the solution models for hornblendes can otherwise be improved.

\section{Analytical techniques}

The hornblendes examined in this study initially were purified for a geochronological investigation using organic heavy-liquid, magnctic-scparation, and hand-picking techniques (Cosca et al. 1991). Based on optical evaluation, the purity of the mineral separates was judged to be $>99 \%$. In a few samples, mineral inclusions of quartz, plagioclase or ilmenite were identified with the aid of backscattered electron imaging, but they constitute $<1 \%$ of the total volume of sample.

\section{Electron-microprobe analyses}

Quantitative electron-microprobe analyses were performed on polished grain mounts of the separated hornblendes. Wavelength-dipersive analyses were obtained using the Cameca CAMEBAX electron microprobe at the University of Michigan. Standard operating conditions consisted of a focused electron beam, an accelerating potential of $15 \mathrm{kV}$, and a sample current of $10 \mathrm{nA}$. the following wcll-characterized standards were used for the analyses: fluor-topaz $(\mathrm{F})$, Irving Kakanui hornblende ( $\mathrm{Na}$ and $\mathrm{Mg}$ ), Ingamells almandine (Al and $\mathrm{Si}$ ), synthetic alforsite (Cl), Gotthard adularia (K), ANU wollastonite (Ca), synthetic geikielite (Ti), ANU rhodonite $(\mathrm{Mn})$ and synthetic ferrosilite $(\mathrm{Fe})$. Counting times were set to $30 \mathrm{~s}$ for major elements, and up to $50 \mathrm{~s}$ for minor elements. Raw data were corrected for atomic number, absorption, and fluorescence using Cameca (PAP) software.

\section{Analyses of ferric iron contents}

The $\mathrm{Fe}^{2+} / \mathrm{Fe}^{3+}$ ratios were determined for the hornblende separates following the procedures of Wilson (1955). Ammonium metavanadate was added to the hornblende to oxidize all $\mathrm{FeO}$ to $\mathrm{Fc}_{2} \mathrm{O}_{3}$, and the amount of $\mathrm{FcO}$ in the sample was determined indirectly by measuring the amount of oxidant reduced. Approximately $0.1 \mathrm{~g}$ of $\mathrm{NH}_{4} \mathrm{VO}_{3}$ was added to $0.2 \mathrm{~g}$ of hornblende and dissolved overnight in approximately $10 \mathrm{ml}$ of concentrated HF. To this solution $30 \mathrm{ml}$ of $10 \mathrm{~N} \mathrm{H}_{2} \mathrm{SO}_{4}, 10 \mathrm{ml}$ of Ba-diphenylaminesulphonate indicator, and approximately $250 \mathrm{ml}$ of saturated $\mathrm{H}_{3} \mathrm{BO}_{3}$ solution were added. The amount of $\mathrm{V}^{5+}$ remaining in solution was determined by titrating this solution with a calibrated solution of ferrous ammonium sulphate, and the amount of $\mathrm{FeO}$ in the hornblende was calculated from mass balance. The amount of $\mathrm{Fc}_{2} \mathrm{O}_{3}$ was calculated from the difference between the total iron as determined on the electron microprobe and the $\mathrm{FeO}$ as determined by wet chemical methods. Replicatc analyscs of $\mathrm{FeO}$ were perforemd on all samples with a precision of $\pm 2.5 \%$ of the amount present.

Alternatively, the amounts of $\mathrm{Fe}^{2+}$ and $\mathrm{Fe}^{3+}$ could have been obtained on bulk samples of hornblende with Mossbauer spectroscopy (e.g., Hawthorne 1983). Spear (1982) gave comparisons of $\mathrm{FeO}$ and $\mathrm{Fe}_{2} \mathrm{O}_{3}$ obtained by Mossbauer methods and stoichiometric estimates that are in fair agreement. Unfortunately, given the multiplicity of possible sites containing $\mathrm{Fe}^{2+}$ and $\mathrm{Fe}^{3+}$, and the scrious overlaps among the Mossbauer absorption peaks, hornblende is not an ideal mineral for Mossbauer measurements. Additional tests of independently analyzed hornblendes arc needed before Mossbauer spectroscopy should be accepted as yielding accurate measurements of total $\mathrm{FeO}$ and $\mathrm{Fe}_{2} \mathrm{O}_{3}$ in hormblende.

\section{Water and $D / H$ determinations}

The $\mathrm{H}_{2} \mathrm{O}$ content and $\delta \mathrm{D}$ value of each hornblende was determined using a hydrogen-isotope-cxtraction line at the University of Utah following the general technique of Friedman (1953). A small amount of hornblende (ca. $0.1 \mathrm{~g}$ ) was first dricd under vacuum at $100^{\circ} \mathrm{C}$ to remove adsorbed (non-structural) water, and then it was fused under vacuum to liberate all structural water. The structural water was collccted and reduced to $\mathrm{H}_{2}$ over uranium metal at approximately $800^{\circ} \mathrm{C}$ (Bigeleisen et al. 1952). The amount of $\mathrm{H}_{2}$ was measured with a standardized $\mathrm{Hg}$ manometer and the $\mathrm{D} / \mathrm{H}$ ratios measured by standard mass-sepctrometry techniques. The prccision of $\mathrm{H}_{2} \mathrm{O}$ determinations for this study, based on replicate analyses, is $\pm 2 \%$. This method is greatly preferred over the traditional method of analysis which involves fusion and trapping of released $\mathrm{H}_{2} \mathrm{O}$ (Penfield 1894), because part of the OH released from hornblende upon heating is driven off as $\mathrm{H}_{2}$. The $\mathrm{H}_{2}$ would not be trapped unless first thoroughly oxidized by a flux such as $\mathrm{PbO}$ or $\mathrm{PbCrO}_{4}$, but such oxidants are not always used even 
Table 1. Hornblende analyses including measured $\mathrm{FeO}, \mathrm{Fe}_{2} \mathrm{O}_{3}, \mathrm{H}_{2} \mathrm{O}$ and $\mathrm{D} / \mathrm{H}$ ratios

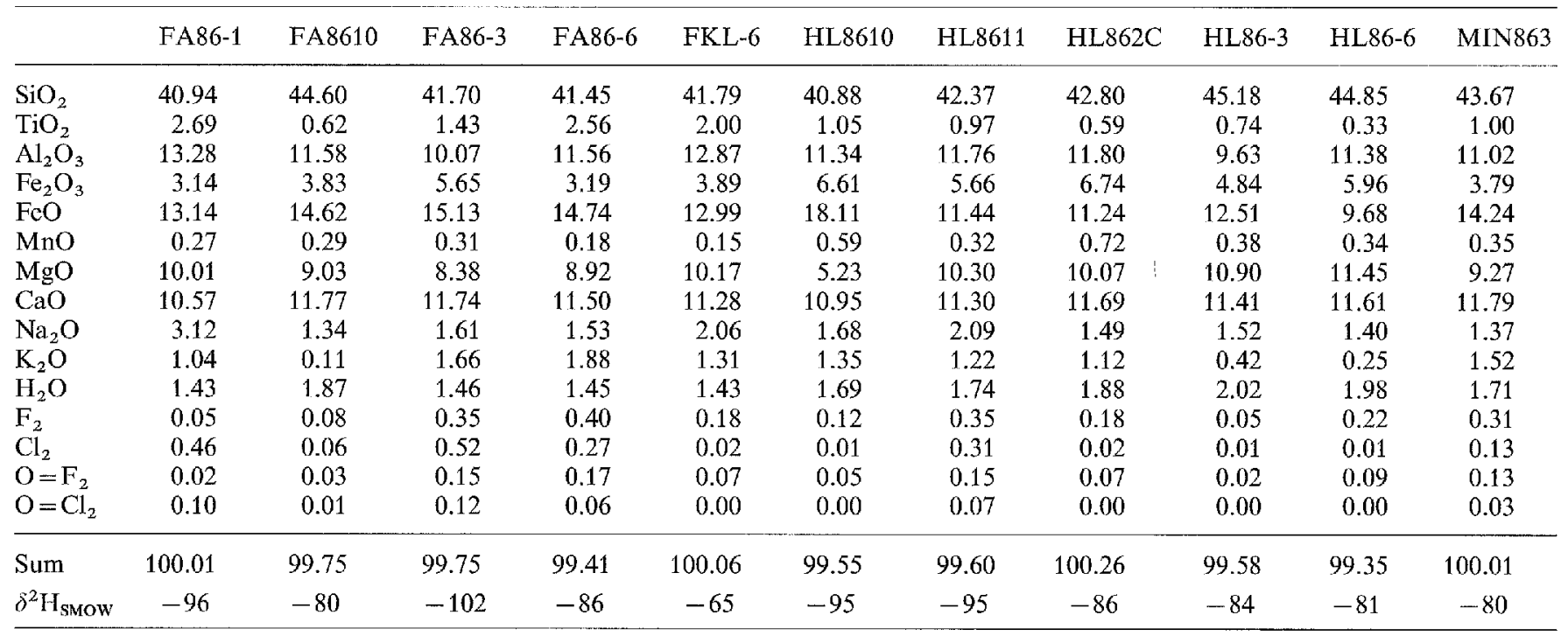

Table 1 (continued)

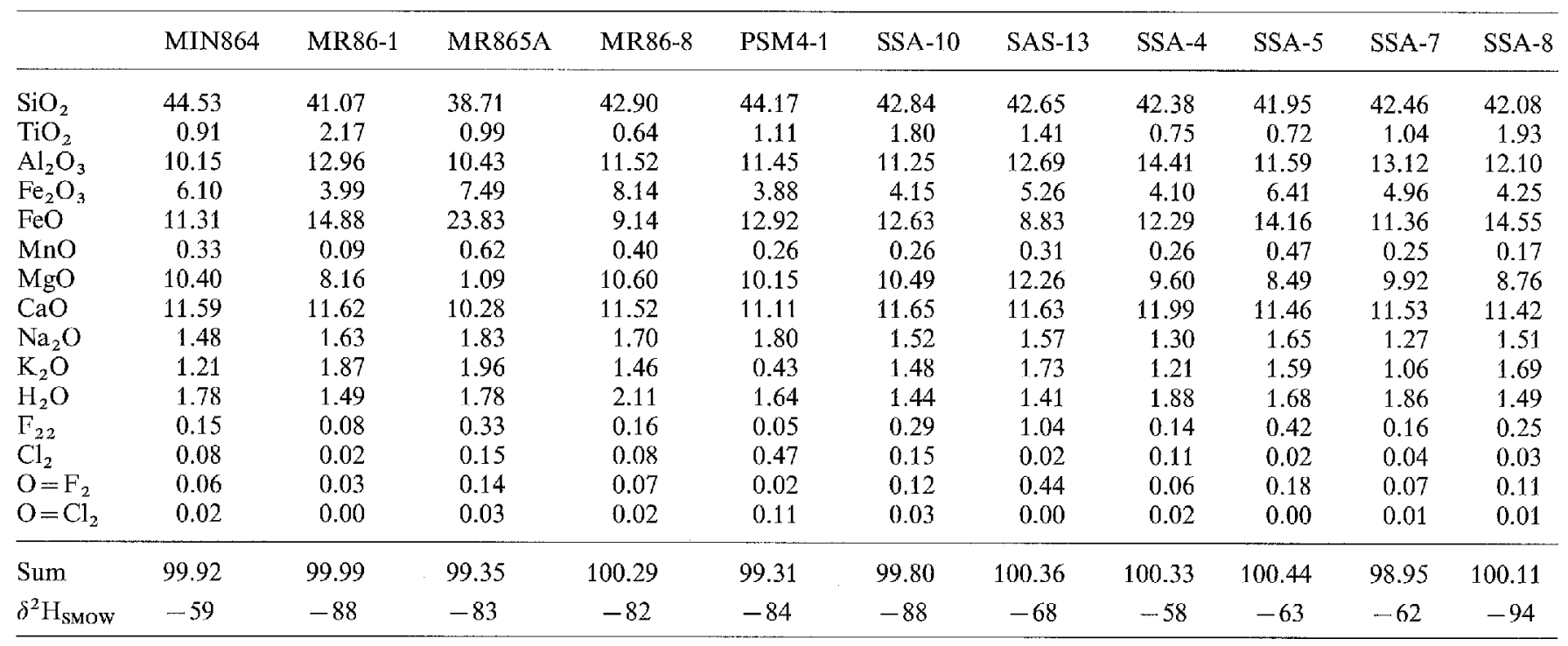

in modifications of the Penficld method (Fairbairn 1951; Shapiro and Brannock 1956). Furthermore, the Penfield method requires $2 \mathrm{gm}$ of sample, which increases the likelihood of analyzing an impure separate. Other comparisons with the techniques used here suggest that the Penfield method is far less precise (JR O'Neil personal communication 1990).

\section{Analytical results}

Chemical and isotopic analyses of the hornblendes including measured $\mathrm{FeO}, \mathrm{Fe}_{2} \mathrm{O}_{3}, \mathrm{H}_{2} \mathrm{O}$, and $\mathrm{D} / \mathrm{H}$ ratios are shown in Table 1. The electron-microprobe data represent average compositions based on at least ten individual analyses. The amphibole formulae in Tables 2-5 were generated with the Minfile program of Afifi and Essene (1989). There is no significant compositional variation between cores and rims of these hornblendes based on electron-microprobe analyses of elements with $Z>8$. The formulae in Table 2 were normalized on the basis of $24=\mathrm{O}+\mathrm{OH}+\mathrm{Cl}+\mathrm{F}$ using the measured $\mathrm{FeO}$, $\mathrm{Fe}_{2} \mathrm{O}_{3}$ and $\mathrm{H}_{2} \mathrm{O}$. Following the terminology of Leake (1978) most of the hornblendes are magnesio-hornblendes, ferroan hastingsitic hornblendes, and ferroan pargasitic hornblendes; their weight fractions of $\mathrm{Fe}_{2} \mathrm{O}_{3}$ / $\left(\mathrm{FeO}+\mathrm{Fe}_{2} \mathrm{O}_{3}\right)$ range from 0.15 to 0.50 , revealing that ferric iron is indeed at significant levels in these hornblendes (Fig. 1). A considerable oxy-hornblende component is present in some of the hornblendes, where as much as $25 \%$ of the $\mathrm{OH}$ site is occupied by $\mathrm{O}$ (Table 2 ). While the possibility of grain to grain variations or zoning in the oxy-amphibole content of an individual hornblende sample cannot be tested with bulk analytical techniques, the optical properties of oxy-amphibole are significantly at variance with the equivalent unoxidized and 
Table 2. Structural formulae calculated on the basis of $\mathrm{O}+\mathrm{OH}+\mathrm{Cl}+\mathrm{F}=24$; includes measured $\mathrm{FeO}, \mathrm{Fe}_{2} \mathrm{O}_{3}$ and $\mathrm{H}_{2} \mathrm{O}$

\begin{tabular}{|c|c|c|c|c|c|c|c|c|c|c|c|}
\hline & FA86-1 & FA8610 & FA86-3 & FA86-6 & FKL-6 & HL8610 & HL8611 & HL862C & HL86-3 & HL86-6 & MIN863 \\
\hline \multicolumn{12}{|c|}{ T sites } \\
\hline $\mathrm{Si}$ & 6.17 & 6.64 & 6.41 & 6.32 & 6.27 & 6.36 & 6.35 & 6.37 & 6.70 & 6.59 & 6.56 \\
\hline \multicolumn{12}{|c|}{ M1, 2, 3 sites } \\
\hline $\mathrm{Al}$ & 0.52 & 0.67 & 0.23 & 0.40 & 0.55 & 0.44 & 0.43 & 0.44 & 0.39 & 0.56 & 0.51 \\
\hline $\mathrm{Fe}^{2+}$ & 1.54 & 1.79 & 1.94 & 1.88 & 1.49 & 2.36 & 1.43 & 1.40 & 1.53 & 1.19 & 1.79 \\
\hline $\mathrm{Mn}$ & 0.03 & 0.04 & 0.04 & 0.02 & 0.02 & 0.08 & 0.04 & 0.09 & 0.05 & 0.04 & 0.04 \\
\hline $\mathrm{Mg}$ & 2.24 & 2.00 & 1.92 & 2.03 & 2.28 & 1.21 & 2.30 & 2.24 & 2.41 & 2.51 & 2.07 \\
\hline $\mathrm{Ca}$ & 0.00 & 0.00 & 0.05 & 0.00 & 0.00 & 0.02 & 0.05 & 0.01 & 0.00 & 0.01 & 0.05 \\
\hline \multicolumn{12}{|c|}{ M4 site } \\
\hline $\mathrm{Na}$ & 0.74 & 0.29 & 0.41 & 0.33 & 0.56 & 0.33 & 0.42 & 0.30 & 0.27 & 0.22 & 0.29 \\
\hline $\mathrm{K}$ & 0.20 & 0.02 & 0.33 & 0.37 & 0.25 & 0.27 & 0.23 & 0.21 & 0.08 & 0.05 & 0.29 \\
\hline Sum & 0.94 & 0.31 & 0.74 & 0.70 & 0.81 & 0.60 & 0.65 & 0.51 & 0.35 & 0.27 & 0.58 \\
\hline \multicolumn{12}{|c|}{ Anion sites } \\
\hline $\mathrm{O}$ & 22.42 & 22.09 & 22.20 & 22.26 & 22.48 & 22.19 & 22.02 & 22.05 & 21.98 & 21.95 & 22.11 \\
\hline $\mathrm{OH}$ & 1.43 & 1.85 & 1.50 & 1.48 & 1.43 & 1.75 & 1.73 & 1.87 & 2.00 & 1.95 & 1.71 \\
\hline F & 0.03 & 0.04 & 0.17 & 0.19 & 0.08 & 0.06 & 0.17 & 0.08 & 0.02 & 0.10 & 0.15 \\
\hline $\mathrm{Cl}$ & 0.12 & 0.02 & 0.13 & 0.07 & 0.01 & 0.00 & 0.08 & 0.00 & 0.00 & 0.00 & 0.03 \\
\hline
\end{tabular}

Table 2 (continued)

\begin{tabular}{|c|c|c|c|c|c|c|c|c|c|c|c|}
\hline & MIN864 & MR86-1 & MR865A & MR86-8 & PSM4-1 & SSA-10 & SAS-13 & SSA-4 & SSA-5 & SSA-7 & SSA-8 \\
\hline \multicolumn{12}{|c|}{ T sites } \\
\hline $\mathrm{Si}$ & 6.62 & 6.24 & 6.26 & 6.34 & 6.60 & 6.44 & 6.27 & 6.27 & 6.34 & 6.35 & 6.36 \\
\hline $\mathrm{Al}$ & 1.38 & 1.76 & 1.74 & 1.66 & 1.40 & 1.56 & 1.73 & 1.73 & 1.66 & 1.65 & 1.64 \\
\hline \multicolumn{12}{|c|}{ M1, 2, 3 sites } \\
\hline Al & 0.40 & 0.57 & 0.24 & 0.35 & 0.61 & 0.43 & 0.47 & 0.78 & 0.41 & 0.66 & 0.52 \\
\hline $\mathrm{Ti}$ & 0.10 & 0.25 & 0.12 & 0.07 & 0.12 & 0.20 & 0.16 & 0.08 & 0.08 & 0.12 & 0.22 \\
\hline $\mathrm{Fe}^{3+}$ & 0.68 & 0.46 & 0.91 & 0.91 & 0.44 & 0.47 & 0.58 & 0.46 & 0.73 & 0.56 & 0.48 \\
\hline $\mathrm{Fe}^{2+}$ & 1.41 & 1.87 & 3.22 & 1.13 & 1.54 & 1.51 & 1.06 & 1.52 & 1.79 & 1.42 & 1.79 \\
\hline $\mathrm{Mn}$ & 0.04 & 0.01 & 0.08 & 0.05 & 0.03 & 0.03 & 0.04 & 0.03 & 0.06 & 0.03 & 0.02 \\
\hline $\mathrm{Mg}$ & 2.31 & 1.85 & 0.26 & 2.34 & 2.26 & 2.35 & 2.69 & 2.12 & 1.91 & 2.21 & 1.97 \\
\hline $\mathrm{Ca}$ & 0.06 & 0.00 & 0.16 & 0.16 & 0.00 & 0.00 & 0.00 & 0.01 & 0.02 & 0.00 & 0.00 \\
\hline \multicolumn{12}{|c|}{ M4 site } \\
\hline $\mathrm{Fe}$ & 0.00 & 0.02 & 0.00 & 0.00 & 0.08 & 0.07 & 0.03 & 0.00 & 0.00 & 0.00 & 0.05 \\
\hline $\mathrm{Ca}$ & 1.85 & 1.89 & 1.78 & 1.82 & 1.78 & 1.88 & 1.83 & 1.90 & 1.86 & 1.85 & 1.85 \\
\hline $\mathrm{Na}$ & 0.15 & 0.08 & 0.22 & 0.18 & 0.14 & 0.05 & 0.14 & 0.10 & 0.14 & 0.15 & 0.10 \\
\hline \multicolumn{12}{|c|}{$\Lambda$ site } \\
\hline $\mathrm{Na}$ & 0.27 & 0.40 & 0.35 & 0.31 & 0.38 & 0.39 & 0.31 & 0.27 & 0.34 & 0.21 & 0.34 \\
\hline $\mathrm{K}$ & 0.23 & 0.36 & 0.41 & 0.28 & 0.08 & 0.28 & 0.33 & 0.23 & 0.31 & 0.20 & 0.33 \\
\hline Sum & 0.50 & 0.76 & 0.76 & 0.59 & 0.46 & 0.67 & 0.64 & 0.50 & 0.65 & 0.41 & 0.67 \\
\hline \multicolumn{12}{|c|}{ Anion sites } \\
\hline 0 & 22.14 & 22.45 & 21.87 & 21.82 & 22.22 & 22.38 & 22.13 & 22.05 & 22.10 & 22.06 & 22.37 \\
\hline $\mathrm{OH}$ & 1.77 & 1.51 & 1.92 & 2.08 & 1.64 & 1.44 & 1.39 & 1.86 & 1.70 & 1.85 & 1.50 \\
\hline $\mathrm{F}$ & 0.07 & 0.04 & 0.17 & 0.08 & 0.02 & 0.14 & 0.48 & 0.06 & 0.20 & 0.08 & 0.12 \\
\hline $\mathrm{Cl}$ & 0.02 & 0.00 & 0.04 & 0.02 & 0.12 & 0.04 & 0.00 & 0.03 & 0.00 & 0.01 & 0.01 \\
\hline
\end{tabular}


Table 3. Structural formulae calculated on the basis of $23 \mathrm{O}-0.5(\mathrm{~F}+\mathrm{Cl})$

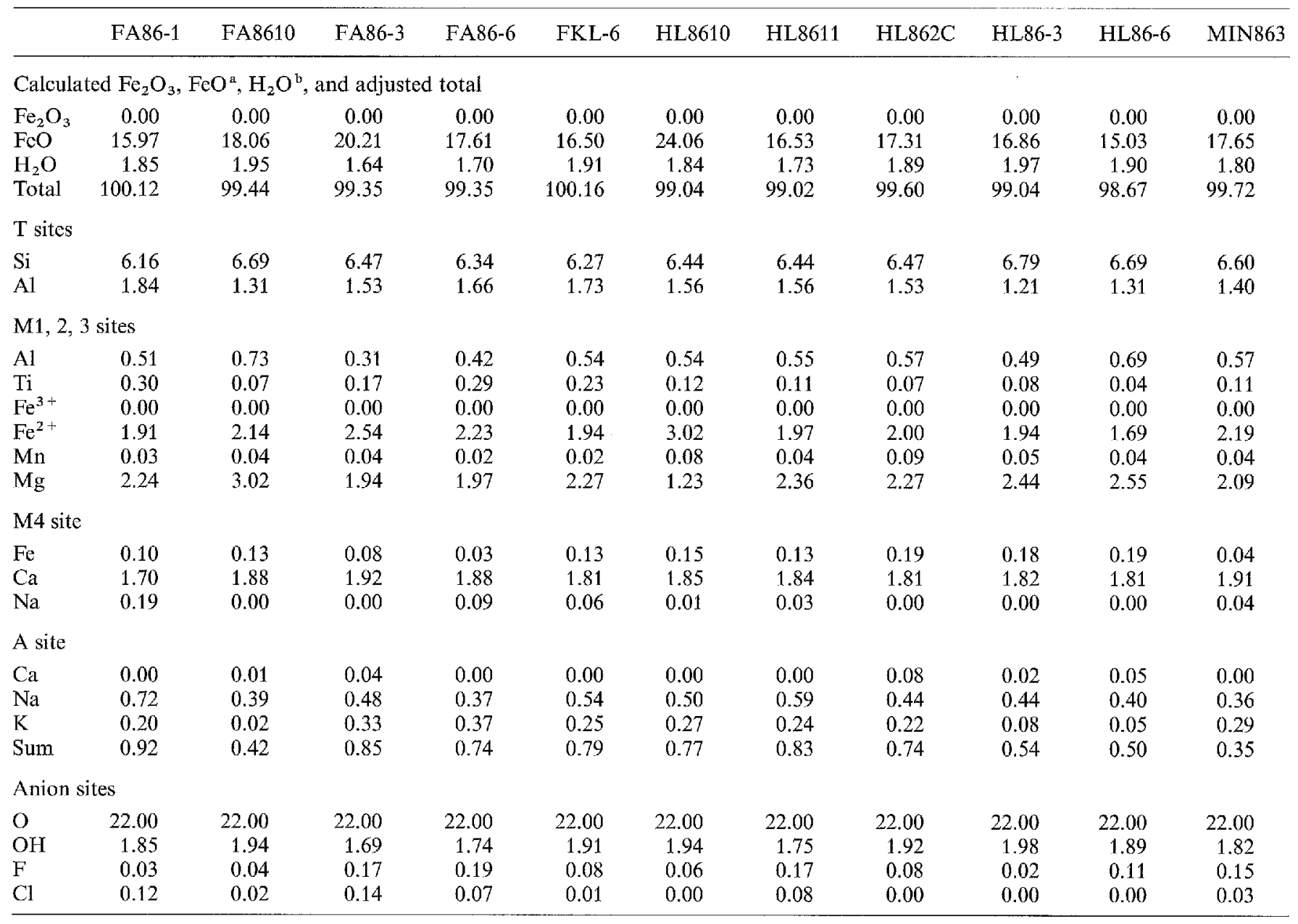

a All Fe assumed as $\mathrm{FeO}$

b Calculated from normalized formula

hydrated amphibole (Deer et al. 1963). The failure to detect obvious variations in the extinction angle and in pleochroism is therefore consistent with little zoning in the oxy-amphibole content. The oxy-hornblende contents in different hornblendes appear to reflect original variations in the oxidation environment in which these various hornblendes equilibrated during metamorphism. The amount of oxy-hornblende component present in these samples suggests that the significant oxy-hornblende substitutions observed and/or expected in extrusive environments (Popp et al. 1990) also occur in metamorphic environments.

The $\delta \mathrm{D}$ values of the hornblendes, expressed relative to Standard Mean Ocean Water (Craig 1951) vary between $-58 \%$ to $-119 \%$. However, the two samples with the lowest $\delta$ D values, FA86-3 (-102) and MR865A (-119) have significantly higher total-iron contents and $\mathrm{Fe} / \mathrm{Mg}$ ratios than the average, suggesting that their significantly lower $\delta \mathrm{D}$ values result from fractionation effects associated with $\mathrm{Fe}$ for $\mathrm{Mg}$ substitutions. The $\delta \mathrm{D}$ values of the remaining samples range from $-58 \%$ to $-96 \%$, typical of metamorphic hornblendes. There is no hydrogen isotopic evidence for post-metamorphic ex- change with D-depleted meteoric waters that could have modified the $\mathrm{Fe}^{3+} / \mathrm{Fe}^{2+}$ and water contents of these hornblendes.

\section{Hornblende normalization schemes}

The task of generating a mineral formula from an electron-microprobe analysis of hornblende is complicated by at least two unknowns, the $\mathrm{H}_{2} \mathrm{O}$ content and the $\mathrm{FeO} / \mathrm{Fe}_{2} \mathrm{O}_{3}$ ratio. Most hornblende analyses determined by electron microprobe are reported on an anhydrous basis with all iron as FeO. Corresponding mineral formulae usually are presented on a basis of 23 oxygens, although this calculation ignores the known substitutions of $\mathrm{O}$ for $\mathrm{OH}$ and of $\mathrm{Fe}^{3+}$ for $\mathrm{Fe}^{2+}$ in hornblende (Robinson et al. 1982). Some estimate of $\mathrm{FeO}, \mathrm{Fe}_{2} \mathrm{O}_{3}$ and $\mathrm{H}_{2} \mathrm{O}$ must be made if accurate hornblende formulae are to be obtained.

In order to test the validity of the normalization of hornblende to 23 oxygens we have recalculated the formulae from the data in Table 1 on the basis of 23 oxygens $[-1 / 2(\mathrm{~F}+\mathrm{Cl})]$ assuming all $\mathrm{Fe}$ as $\mathrm{Fe}^{2+}$ (Table 3$)$. 
Table 3 (continued)

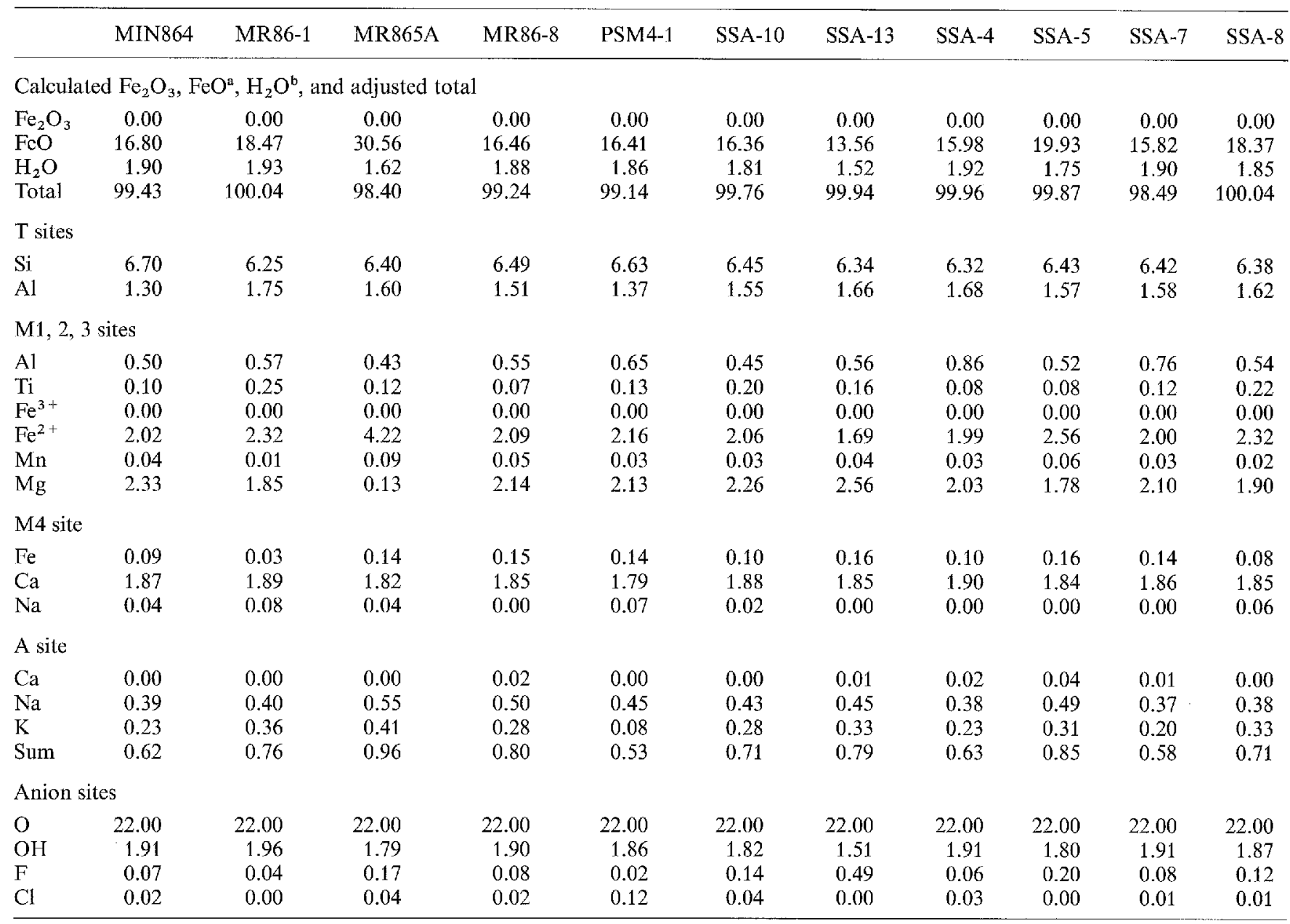

a All Fe assumed as $\mathrm{FeO}$

' Calculated from normalized formula

The $\mathrm{H}_{2} \mathrm{O}$ contents of hornblendes presented in Table 3 were calculated assuming $\mathrm{OH}=2-\mathrm{F}-\mathrm{Cl}$. When comparing the formulae presented in Tables 2 and 3 , the amount of ferrous iron is overestimated on a 23 anion basis by $21-85 \%$, which produces serious errors in the calculated $\mathrm{Mg} / \mathrm{Fe}^{2+}$ ratios. Many of these hornblendes have excess oxygen in the $\mathrm{OH}$ site, requiring normalization to more than 23 oxygens if anion normalization is used. Once electron-microprobe analyses of amphiboles are normalized to 23 oxygens, there is no unique method to estimate the $\mathrm{FeO} / \mathrm{Fe}_{2} \mathrm{O}_{3}$ ratio, as conversion of $\mathrm{FeO}$ to $\mathrm{Fe}_{2} \mathrm{O}_{3}$ increases the moles of oxygen by half of the moles of $\mathrm{Fe}^{3+}$ that are inferred to be present. The resultant inaccuracies will preclude accurate calculations of $K_{\mathrm{D}}$ relations involving $\mathrm{Mg} / \mathrm{Fe}^{2+}$ between hornblende and other ferromagnesian silicates using electronmicroprobe analyses alone (cf. Graham and Powell 1984). In order to obtain a more accurate estimate of $\mathrm{Fe}^{2+} / \mathrm{Fe}^{3+}$ ratios in hornblende, two alternative cationnormalization schemes have been considered.

One approach to calculating hornblende formulae from electron-microprobe data is based on a fixed sum of cations (e.g. Stout 1972; Robinson et al. 1982). With this technique it is assumed that a specified number of cations are stoichiometric for a given mineral; this procedure is widely used today for normalizing mineral formulae from electron-microprobe data for many minerals including garnets, clinopyroxenes, feldspars and magnetites. For hornblendes, the crystallographic site preferences for most common elements have been determined by X-ray structure refinements, which indicate site preferences of $\mathrm{Si}>\mathrm{Al}>\mathrm{Fe}^{3+}>\mathrm{Ti}$ in tetrahedral sites, $\mathrm{Al}>$ $\mathrm{Ti}>\mathrm{Fe}^{3+}>\mathrm{Fe}^{2+}>\mathrm{Mg}>\mathrm{Mn}>\mathrm{Ca}$ in the $\mathrm{M} 1, \mathrm{M} 2$, and M3 sites, $\mathrm{Ca}>\mathrm{Na}>\mathrm{Fe}^{2+}$ in the M4 site, and $\mathrm{K}>\mathrm{Na}$ in the A site (cf. Hawthorne 1983). Because X-ray data indicate that the tetrahedral and M1, M2, M3 and usually the M4 sites in hornblendes are filled (i.e., have no vacancies) a mineral formula may be calculated based on fixed-cation occupancies in these sites. Normalization of calcium amphiboles on the basis of a fixed number of octahedral and tetrahedral cations satisfies most crystal-chemical relations.

Hornblende formulae normalized to $13=\mathrm{Si}+\mathrm{Ti}+$ $\mathrm{Al}+\mathrm{Fe}+\mathrm{Mn}+\mathrm{Mg}$ in the T, M1, M2 and M3 sites are shown in Table 4 . This procedure necessarily excludes any $\mathrm{Fe}^{2+}, \mathrm{Mn}$ or $\mathrm{Mg}$ from the $\mathrm{M} 4$ site and any $\mathrm{Ca}$ 
Table 4. Structural formulae calculated on the basis of $\mathrm{Si}+\mathrm{Ti}+\mathrm{Al}++\mathrm{Fe}+\mathrm{Mn}+\mathrm{Mg}=13$

\begin{tabular}{|c|c|c|c|c|c|c|c|c|c|}
\hline FA86-1 & FA8610 & FA86-3 & FA86-6 & FKL-6 & HL8610 & HL8611 & HL862C & HL86-3 & HL86-6 \\
\hline
\end{tabular}

Calculated ${ }^{\mathrm{a}} \mathrm{Fe}_{2} \mathrm{O}_{3}, \mathrm{FeO}, \mathrm{H}_{2} \mathrm{O}$, and adjusted total

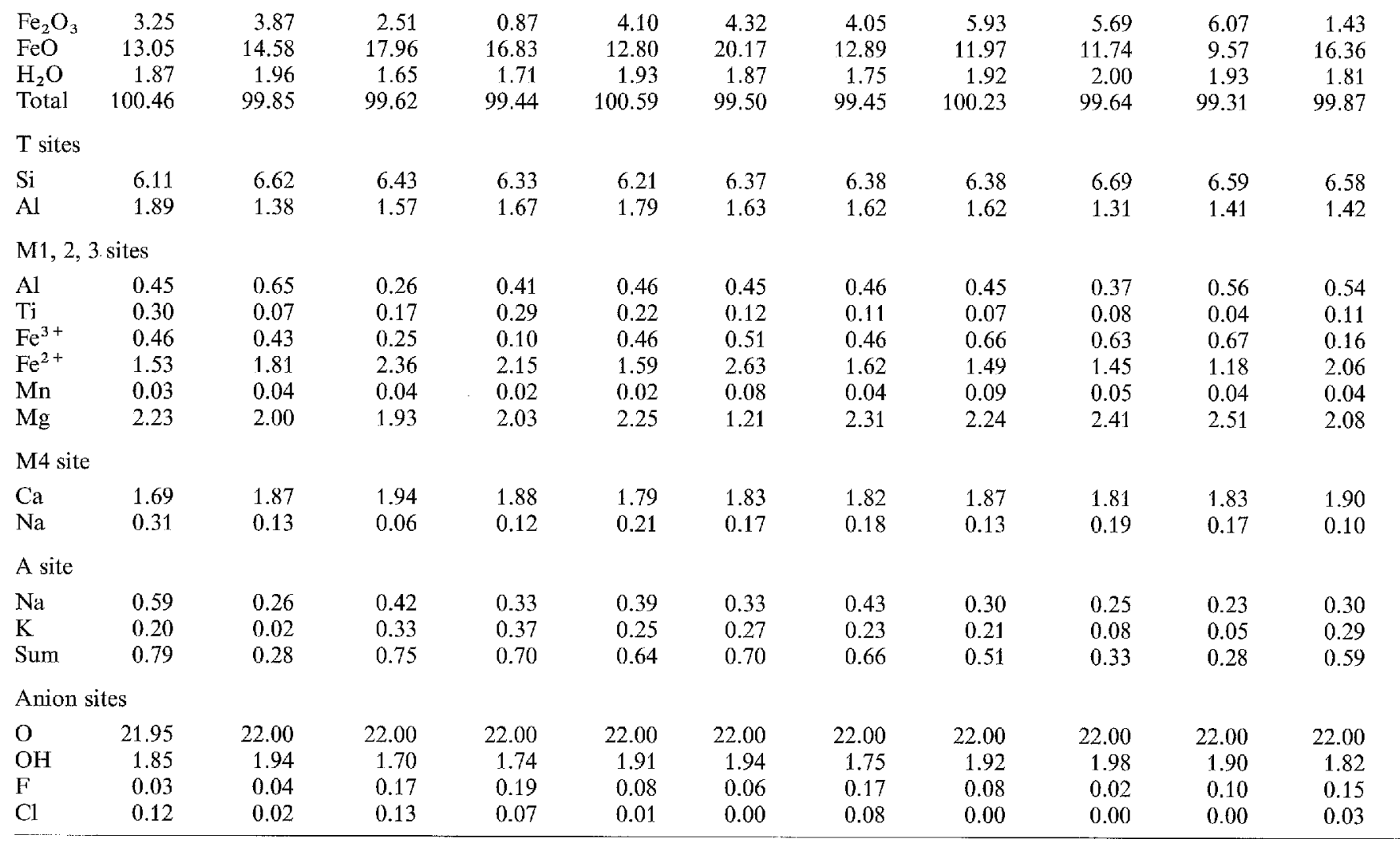

Table 4 (continued)

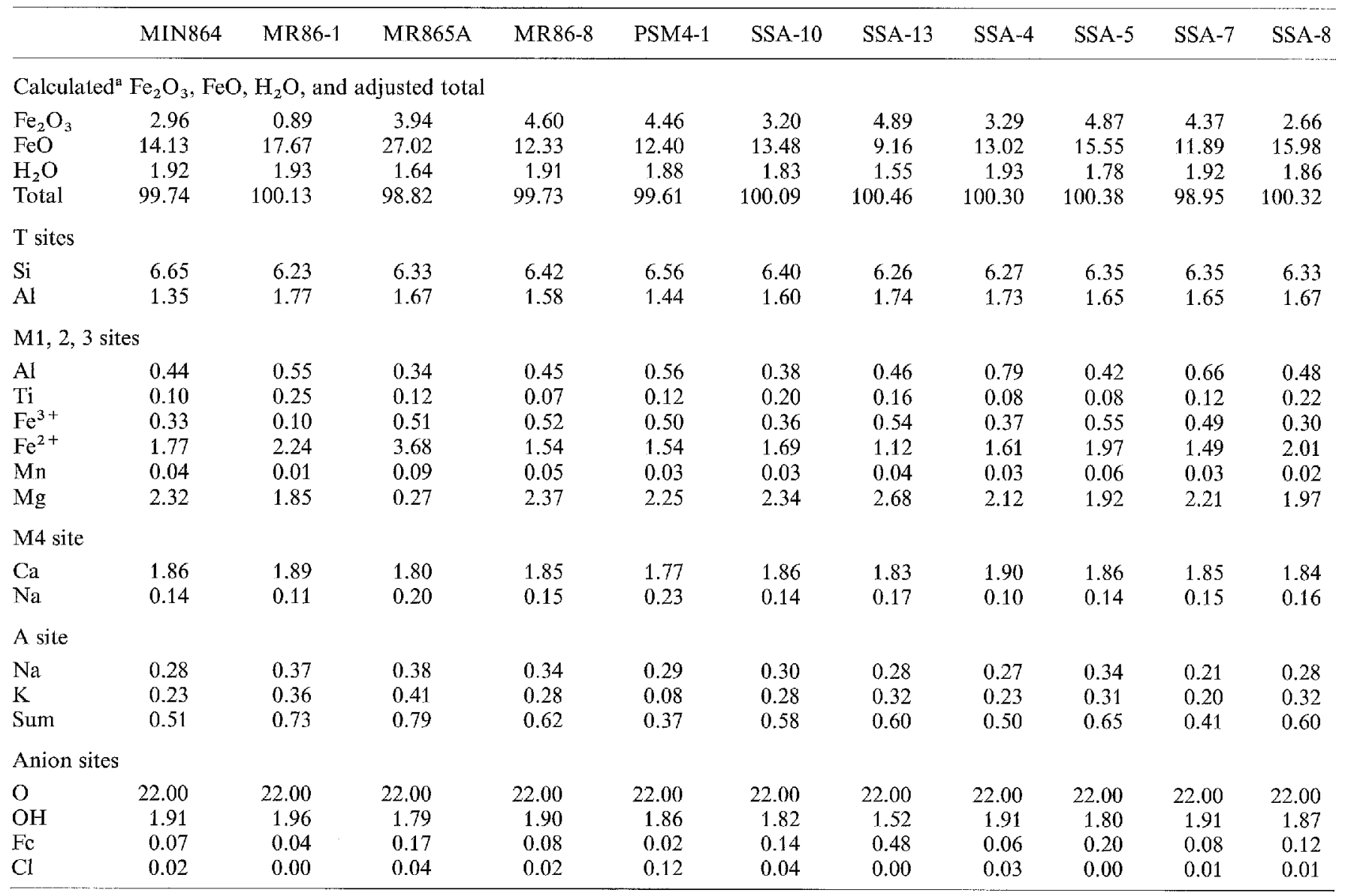

a Calculated from normalized formula 
Table 5. Structural formulae calculated on the basis of $\mathrm{Si}+\mathrm{Ti}+\mathrm{A} 1+\mathrm{Fe}+\mathrm{Mn}+\mathrm{Mg}+\mathrm{Ca}=15$

FA86-1 FA8610 FA86-3 FA86-6 FKL-6 HL8610 HL8611 HL862C HL86-3 HL86-6 MIN863

Calculated ${ }^{\mathrm{a}} \mathrm{Fe}_{2} \mathrm{O}_{3}, \mathrm{FeO}, \mathrm{H}_{2} \mathrm{O}$, and adjusted total

\begin{tabular}{|c|c|c|c|c|c|c|c|c|c|c|c|}
\hline $\mathrm{Fe}_{2} \mathrm{O}_{3}$ & 0.00 & 0.40 & 0.92 & 0.00 & 0.00 & 0.00 & 0.00 & 2.29 & 0.47 & 1.30 & 0.00 \\
\hline $\mathrm{H}_{2} \mathrm{O}$ & 1.53 & 1.95 & 1.64 & 1.56 & 1.82 & 1.83 & 1.68 & 1.91 & 1.97 & 1.91 & 1.73 \\
\hline Total & 99.79 & 99.48 & 99.45 & 99.20 & 100.07 & 99.03 & 98.98 & 99.84 & 99.09 & 98.81 & 99.64 \\
\hline $\mathrm{Si}$ & 6.24 & 6.68 & 6.46 & 6.38 & 6.29 & 6.44 & 6.45 & 6.43 & 6.78 & 6.67 & 6.62 \\
\hline $\mathrm{Al}$ & 1.76 & 1.32 & 1.54 & 1.62 & 1.71 & 1.56 & 1.55 & 1.57 & 1.22 & 1.33 & 1.38 \\
\hline $\mathrm{Ti}$ & 0.31 & 0.07 & 0.17 & 0.30 & 0.23 & 0.12 & 0.11 & 0.07 & 0.08 & 0.04 & 0.11 \\
\hline $\mathrm{Fe}^{3+}$ & 0.00 & 0.05 & 0.11 & 0.00 & 0.00 & 0.00 & 0.00 & 0.26 & 0.05 & 0.15 & 0.00 \\
\hline $\mathrm{Fc}^{2+}$ & 1.76 & 2.10 & 2.46 & 2.16 & 1.90 & 3.02 & 1.95 & 1.80 & 2.24 & 1.58 & 2.15 \\
\hline $\mathrm{Mn}$ & 0.03 & 0.04 & 0.04 & 0.02 & 0.02 & 0.08 & 0.04 & 0.09 & 0.05 , & 0.04 & 0.05 \\
\hline $\mathrm{Mg}$ & 2.27 & 2.02 & 1.94 & 2.05 & 2.28 & 1.23 & 2.34 & 2.26 & 2.44 & 2.54 & 2.10 \\
\hline $\mathrm{Na}$ & 0.92 & 0.39 & 0.48 & 0.46 & 0.60 & 0.51 & 0.62 & 0.44 & 0.44 & 0.40 & 0.40 \\
\hline $\mathrm{K}$ & 0.20 & 0.02 & 0.33 & 0.37 & 0.25 & 0.27 & 0.24 & 0.21 & 0.08 & 0.05 & 0.29 \\
\hline Sum & 1.12 & 0.41 & 0.81 & 0.83 & 0.85 & 0.78 & 0.86 & 0.65 & 0.52 & 0.45 & 0.69 \\
\hline \multicolumn{12}{|c|}{ Anion sitcs } \\
\hline $\mathrm{O}$ & 22.44 & 22.00 & 22.00 & 22.21 & 22.14 & 22.01 & 22.07 & 22.00 & 22.00 & 22.00 & 22.10 \\
\hline $\mathrm{OH}$ & 1.55 & 1.94 & 1.69 & 1.61 & 1.83 & 1.93 & 1.71 & 1.92 & 1.98 & 1.89 & 1.75 \\
\hline $\mathrm{F}$ & 0.03 & 0.04 & 0.17 & 0.19 & 0.08 & 0.06 & 0.17 & 0.08 & 0.02 & 0.11 & 0.15 \\
\hline $\mathrm{Cl}$ & 0.12 & 0.02 & 0.14 & 0.07 & 0.01 & 0.00 & 0.08 & 0.00 & 0.00 & 0.00 & 0.03 \\
\hline
\end{tabular}

Table 5 (continued)

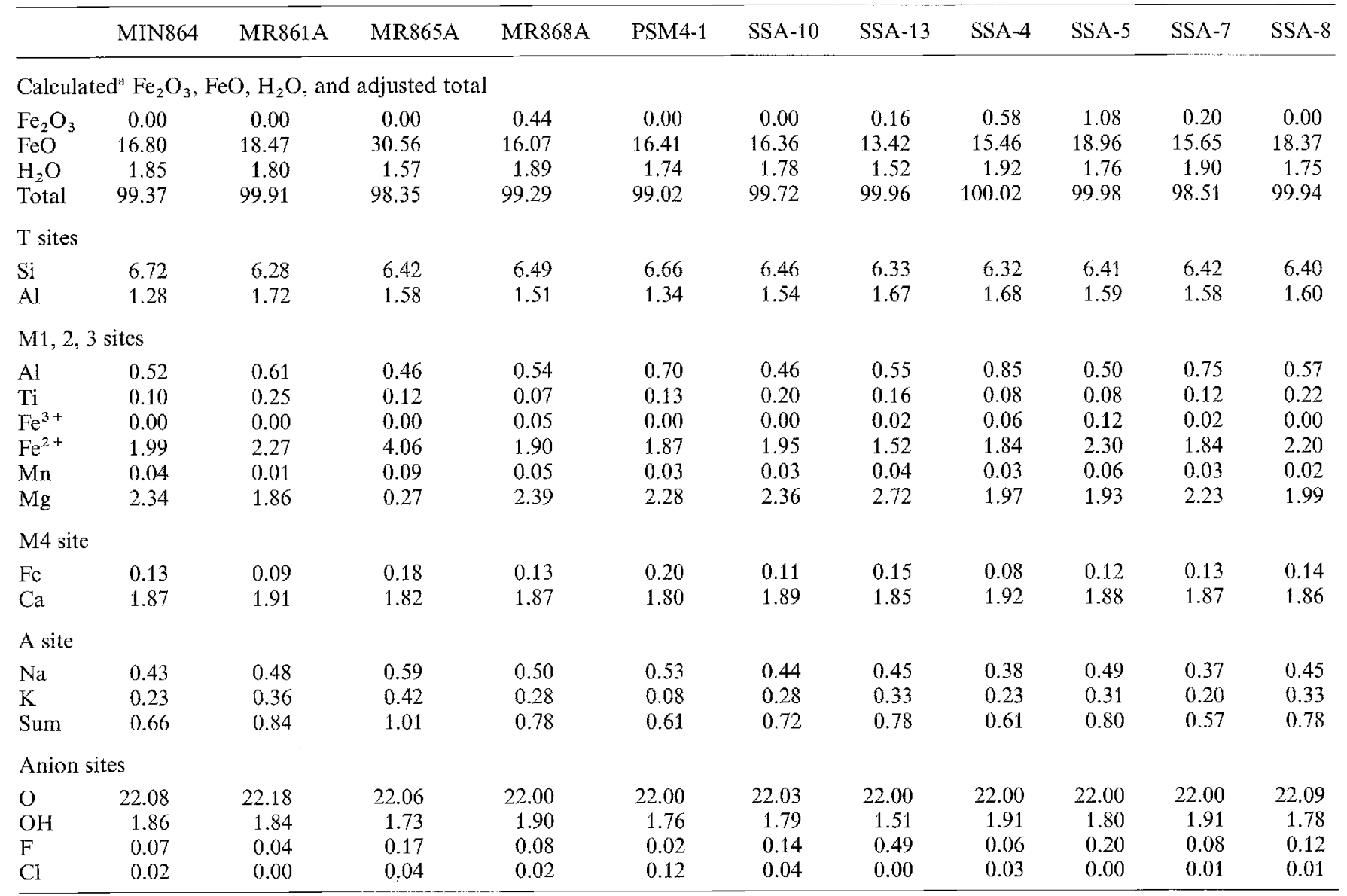

${ }^{a}$ Calculated from normalized formula 


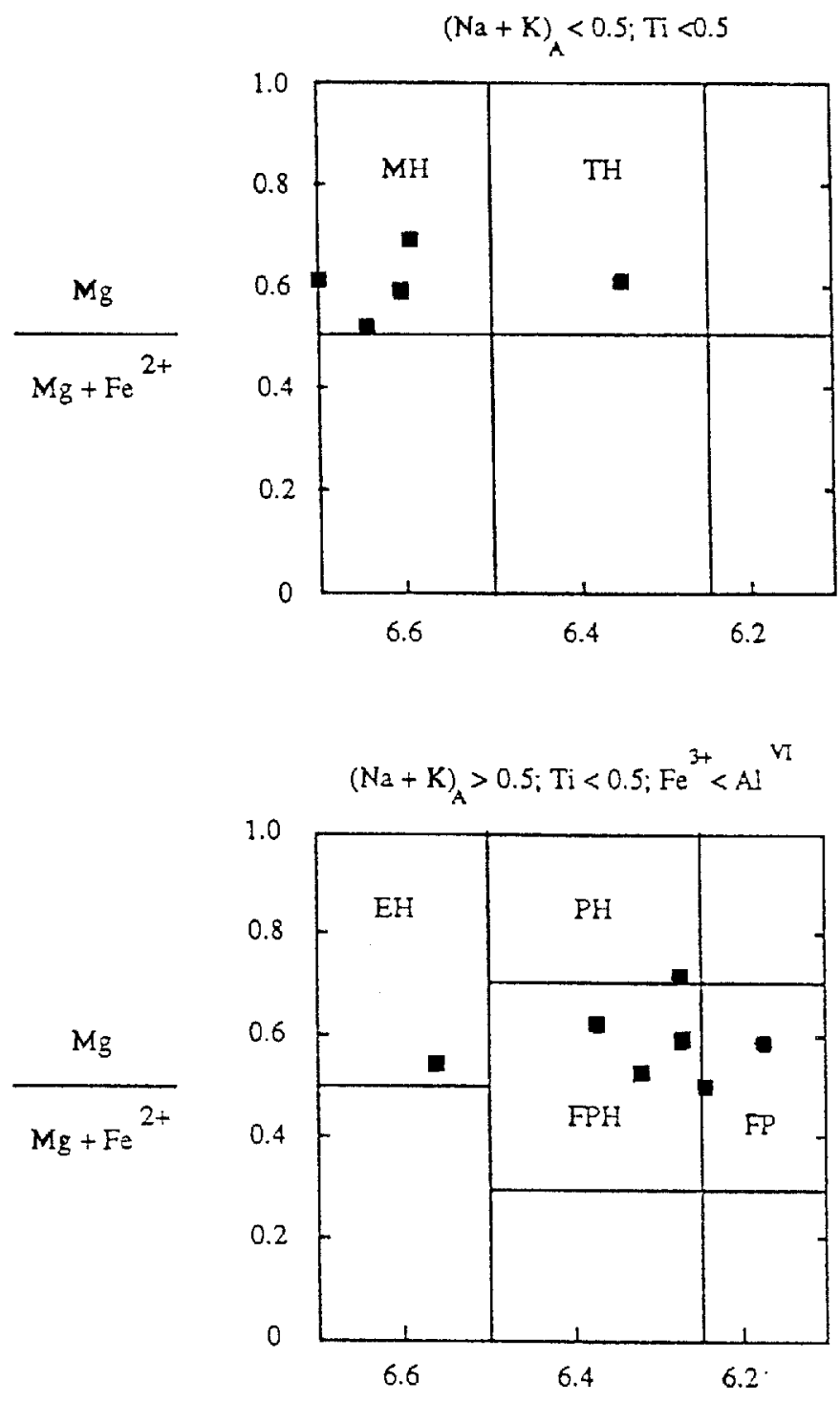

Fig. 1. Plots of amphiboles analyzed for this study on the diagram of Leake (1978). $M H$, magnesio-hornblende; $T H$, tschermakitic hornblende; $E H$, edenitic homblende; $P H$, pargasitic hornblende; $F P H$, ferroan pargasitic hornblende; $F P$, ferroan pargasite; $M H H$, magnesian hastingsitic hornblende; $H H$, hastingsitic hornblende

from the M1, M2, or M3 sites. The molecular proportions of $\mathrm{OH}$ and the equivalent weight percent $\mathrm{H}_{2} \mathrm{O}$ were calculated assuming $\mathrm{OH}=2-\mathrm{Cl}-\mathrm{F}$, and the $\mathrm{Fe}^{2+} / \mathrm{Fe}^{3+}$ ratios were estimated from charge balance. Comparison of these formulae with those presented in Table 2 indicates good agreement in measured vs calculated $\mathrm{FeO}$ and in the distributions of elements, but poor agreement in measured vs estimated $\mathrm{H}_{2} \mathrm{O}$. The differences between the formulae in Tables 2 and 4 are due mainly to excess $\mathrm{O}$ inferred to occupy the $\mathrm{OH}$ sites in some samples. The 13 cation normalization procedure excludes the possibility of $\mathrm{Fe}^{2+}$ substitution in M4, which may be significant in highly subcalcic hornblendes that cocxist with cummingtonite or hypersthene.

An alternative normalization procedure was performed with the electron-microprobe data on the basis

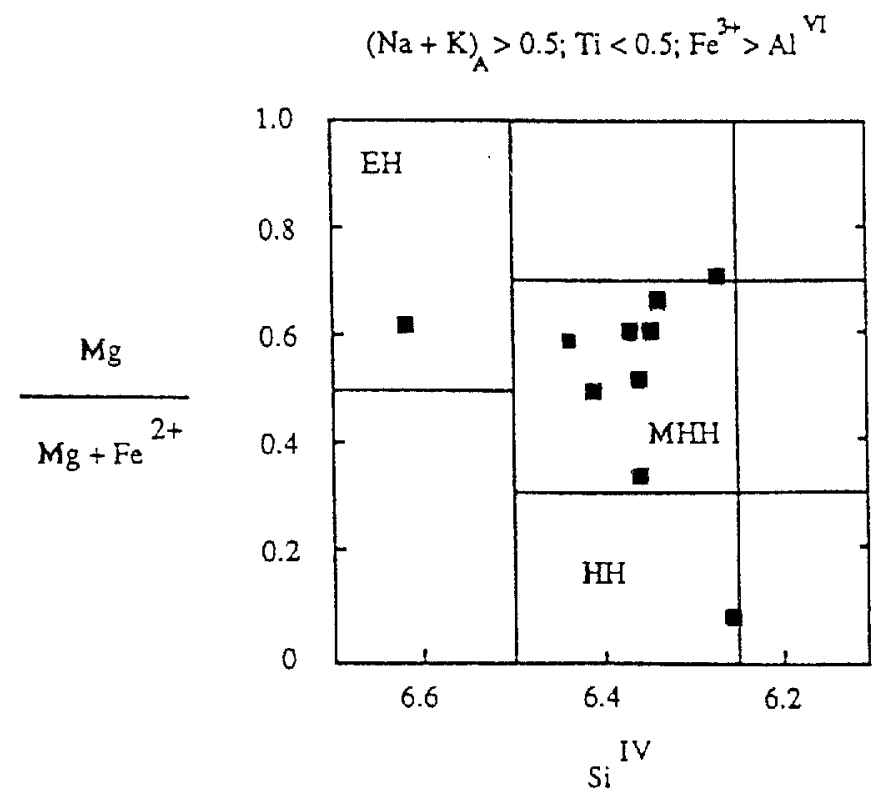

of $15=\mathrm{Si}+\mathrm{Ti}+\mathrm{Al}+\mathrm{Fe}+\mathrm{Mn}+\mathrm{Mg}+\mathrm{Ca}$ in $\mathrm{T}, \mathrm{M} 1, \mathrm{M} 2$, M3 and M4 (Table 5). The formulae calculated on a 15 cation basis agree less satisfactorily with those presented in Table 2 than formulae calculated on the basis of 13 cations due to substitution of $\mathrm{Na}$ in M4 for some samples, although the differences are relatively small for these hornblendes as they are not highly subcalcic (Table 2). Because $\mathrm{Na}$ is excluded from the normalizing base, the sum of the remaining small cations is overestimated by an amount directly proportional to the actual amount of $\mathrm{Na}$ in M4. In some cases, 15 cation normalizations of hornblendes lead to an excess positive charge, which necessitates an apparent $\mathrm{O}$ substitution for $\mathrm{OH}$ in the hydroxyl site in order to maintain charge balance (Table 5).

Although the 15 cation normalization scheme is widely thought to provide an upper limit to the amount of ferric iron (Stout 1972; Robinson et al. 1982; Spear 1982), this cannot be the case when a significant oxyamphibole component substitutes in hornblende. No cation-based scheme can be used to detect the difference between $\mathrm{Fe}^{2+} \mathrm{OH}$ and $\mathrm{Fe}^{3+} \mathrm{O}$ in hornblende, because the amount of iron and the total charge is the same in both cases. The only limit that can be placed on ferric iron is when no hydroxyl ion is left to be converted to oxygen or when all ferrous iron is oxidized to ferric iron. This little-appreciated inference is equally applicable to cation normalizations of other amphiboles, allanites, chlorites, clay minerals, hoegbomites, illites, micas, pumpellyites, staurolites, vesuvianites, i.e., all hydroxyl-bearing minerals that may contain both ferric and ferrous iron.

The differences between normalization schemes can be viewed by comparison with the formulae presented in Table 2. For elements other than Fe, the cation-site assignments from the various normalization schemes yield relatively small differences. However, significant differences in the estimated $\mathrm{Fe}^{2+} / \mathrm{Fe}^{3+}$ ratios are obtained in the different procedures. Figure 2 is a plot of 


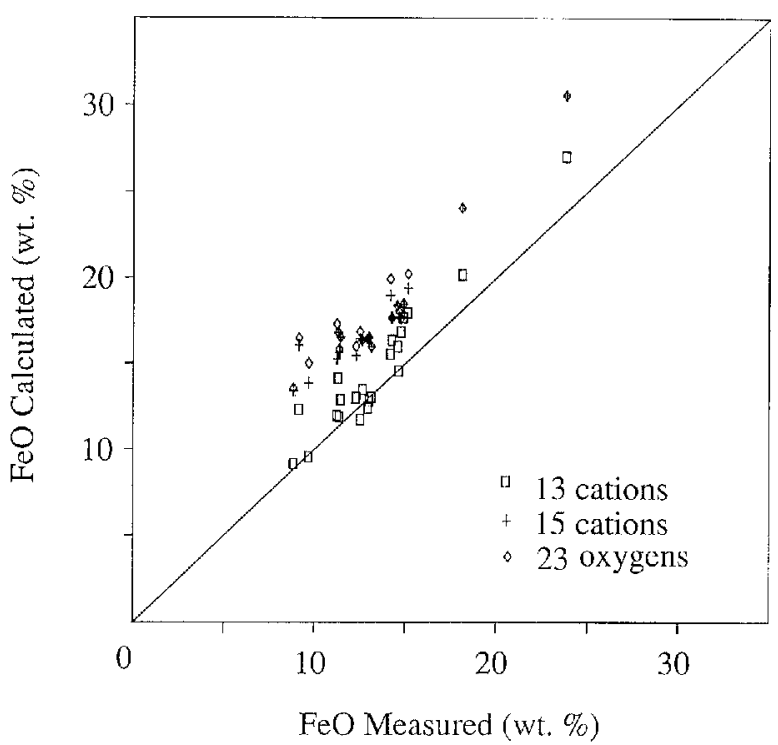

Fig. 2. Plot of measured vs calcualted $\mathrm{FeO}$ for hornblendes investigated in this study. Normalization schemes described in text

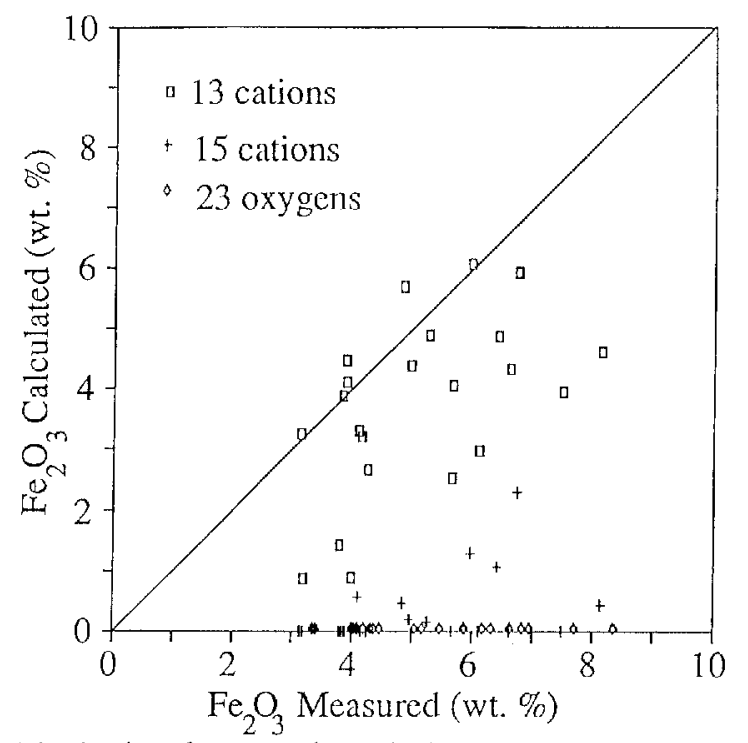

Fig. 3. Plot of measured vs calculated $\mathrm{Fe}_{2} \mathrm{O}_{3}$ for hornblendes investigated in this study. Normalization schemes described in text

the amount of $\mathrm{FeO}$ determined by titration vs the amount of $\mathrm{FeO}$ calculated from each of the normalization schemes outlined above. Similarly, a plot of measured vs calculated $\mathrm{Fe}_{2} \mathrm{O}_{3}$ is presented in Fig. 3. Although not in perfect agreement, the results presented in Figs. 2 and 3 indicate that fairly reasonable estimates of $\mathrm{FeO}$ and $\mathrm{Fe}_{2} \mathrm{O}_{3}$ may be obtained after normalization on the basis of 13 small cations. All normalizations tend to underestimate the amount of $\mathrm{Fe}_{2} \mathrm{O}_{3}$ and to overestimate the amount of $\mathrm{FeO}$ (Figs. 2, 3), but the best normalization scheme for estimating $\mathrm{Fe}^{2+} / \mathrm{Fe}^{3+}$ ratios of these amphiboles is based on 13 small cations (Fig. 4). In contrast, there is no systematic reltionship between measured and calculated $\mathrm{H}_{2} \mathrm{O}$ contents from the different normalization schemes, although the estimates of $\mathrm{H}_{2} \mathrm{O}$ are generally higher than measured values. The

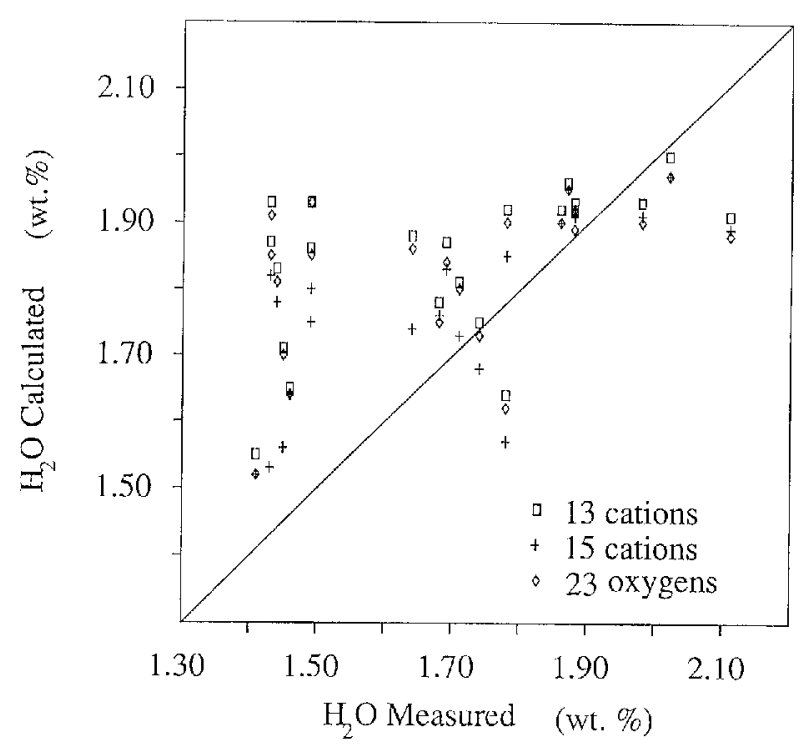

Fig. 4. Plot of measured vs calculated $\mathrm{H}_{2} \mathrm{O}$ for hornblendes investigated in this study. Normalization schemes described in text

poor agreement suggests that $\mathrm{H}_{2} \mathrm{O}$ contents of hornblendes should not be estimated from electron-microprobe data alone even if $\mathrm{F}_{2}$ and $\mathrm{Cl}_{2}$ are analyzed and that the $\mathrm{H}_{2} \mathrm{O}$ content of hornblende should only be determined by direct measurement.

\section{Effects on $a_{\mathrm{H}_{2} \mathrm{O}}$ calculations}

Hornblende should be useful in constraining the $a_{\mathrm{H}_{2} \mathrm{O}}$ especially in rocks metamorphosed to the granulite facies, which are generally believed to have formed under relatively "dry" (i.e., $P_{\mathrm{H}_{2} \mathrm{O}}<P_{\text {solid }}$ ) and fluid-absent (i.e., $P_{\text {fluid }}<P_{\text {solid }}$ ) conditions. However, the occurrence in many granulites of $\mathrm{OH}-, \mathrm{F}-$, and/or Cl-bearing minerals, such as hornblende or biotite, indicates the presence of some fluid components locked up in the solids during metamorphism. The activities of fluid components buffered by the coexisting solids are essential in constraining the former presence or absence of a fluid phase and the formation of a melt phase in granulites. Unfortunately, accurate estimates of the activities of major fluid species are difficult to obtain in most igneous or metamorphic rocks.

Investigations aimed at constraining fluid compositions in high-grade rocks have relied on phase equilibria involving biotite (e.g., Bohlen et al. 1980; Phillips 1980; Edwards and Essene 1988) or amphibole (e.g., Phillips 1980; Valley et al. 1982; Ghent 1988; Lamb and Valley 1988). For granulite facies assemblages containing tremolitic amphiboles, several reactions have been applied that constrain $\mathrm{H}_{2} \mathrm{O}$ activity during metamorphism (e.g., Valley et al. 1982, 1983, 1990; Ghent 1988; Lamb and Valley 1988). However, for granulites containing hornblende rather than tremolite, a reduced $\mathrm{Ca}_{2} \mathrm{Mg}_{5} \mathrm{Si}_{8}$ $\mathrm{O}_{22}(\mathrm{OH})_{2}$ activity $\left(a_{\text {Trem }}\right)$ must be calculated from a hornblende analysis if the same equilibria are to be applied. Unfortunately, no measured $a-X$ relations are 


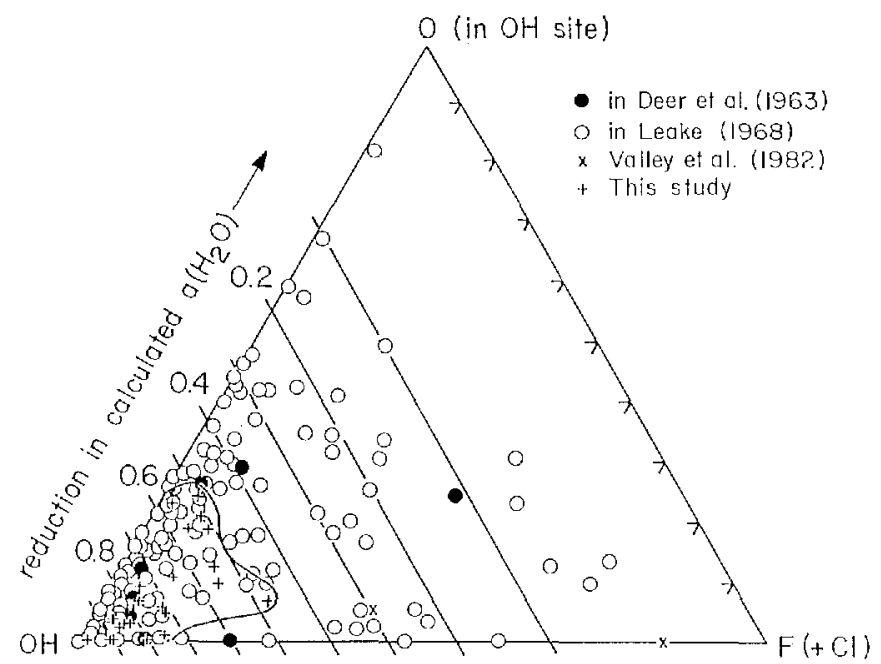

Fig. 5. Plot of hydroxyl site occupancy of amphiboles from this study together with data from other workers. Also shown arc lincs of reduced $\mathrm{H}_{2} \mathrm{O}$ (and hydroxyl-amphibole) activity assuming an ionic solution model on the hydroxyl site

as yet available for calcic amphiboles, and the ionic models that have thus far been proposed are extremely sensitive to composition (Ghent 1988). As a result, attempts to constrain $\mathrm{H}_{2} \mathrm{O}$ activities using equilibria applied to most natural assemblages with hornblende yield unreasonably low values and highly imprecise results (e.g., Phillips 1980; Ghent 1988; Lamb and Valley 1988; Valley et al. 1990). Ionic solution models applied to hornblende compositions are, in addition, highly sensitive to $\mathrm{F}, \mathrm{Cl}$, and $\mathrm{O}$ substitutions in the $\mathrm{OH}$ site. For instance, if an ionic solution model of the form $a_{\text {Trem }}=$ $\left(X_{\mathrm{b}}^{\mathrm{A}}\right)\left(X_{\mathrm{Ca}}^{\mathrm{M} 4}\right)^{2}\left(X_{\mathrm{Mg}}^{\mathrm{M} 1,2,3}\right)^{5}\left(X_{\mathrm{Si}}^{\mathrm{T}}\right)^{8}\left(X_{\mathrm{OH}}\right)^{2}$ (e.g., Powell 1975) or if a locally charge balanced model such as $\left(X_{\mathrm{D}}^{\mathrm{A}}\right)$ $\left(X_{\mathrm{Ca}}^{\mathrm{M} 4}\right)^{2}\left(X_{\mathrm{Mg}}^{\mathrm{M} 1,3}\right)^{3}\left(X_{\mathrm{Mg}}^{\mathrm{M} 2}\right)^{2}\left(X_{\mathrm{OH}}\right)^{2}$ (e.g., Essene 1989) is used for hornblende, substitution of $\mathrm{F}, \mathrm{Cl}$, and $\mathrm{O}$ in the hydroxyl site may significantly reduce the calculated $a_{\text {Trem }}$ and $a_{\mathrm{H}_{2} \mathrm{O}}$. To illustrate these effects and their influence on calculated $\mathrm{H}_{2} \mathrm{O}$ activity based on an ideal ionic solution model of $\mathrm{OH}-\mathrm{F}-\mathrm{Cl}-\mathrm{O}$ exchange for hornblende (and biotite), the measured hydroxyl-site occupancies of hornblendes from this study are plotted for hornblende together in Fig. 5 with similarly characterized hornblendes from the literature. Substitution of $25 \mathrm{~mol} \% \mathrm{O}$ and/or $\mathrm{F}$ for $\mathrm{OH}$ is common in hornblende (Fig. 5). For an ideal $\mathrm{OH}$-site mixing model, substitution of $25 \% \mathrm{~F}+$ $\mathrm{Cl}+\mathrm{O}$ for $\mathrm{OH}$ decreases the calculated $\mathrm{H}_{2} \mathrm{O}$ activity by $50 \%$. Substitution of greater $\mathrm{O}$ for $\mathrm{OH}$ (Fig. 5) may indicate lower $\mathrm{H}_{2} \mathrm{O}$ activity, although late oxidation of hornblende will also decrease the $\mathrm{H}_{2} \mathrm{O}$ content and increase the $\mathrm{Fe}_{2} \mathrm{O}_{3} / \mathrm{FeO}$ ratio concomitantly (Deer et al. 1963). Conversely, inclusion of more hydrous alteration products such as chlorite will increase the apparent $\mathrm{H}_{2} \mathrm{O}$ content of an impure separate. Quantitative microanalytical techniques such as ion-microprobe or laser-Raman analysis on a more routine basis could minimize such problems and could also be used to evaluate zoning of $\mathrm{OH}$. Nonetheless, determination of such substitutions in optically pure bulk samples is still important especial- ly if hornblendes are seen to be unzoned by optical and microprobe observations.

Substitutions of $\mathrm{F}$ and $\mathrm{Cl}$ in hornblendes may be evaluated by electron-microprobe analysis, but the $\mathrm{H}_{2} \mathrm{O}$ content is generally estimated by assuming that $\mathrm{OH}(+\mathrm{F}+$ Cl) fully occupies the hydroxyl site. The substitution of $\mathrm{O}$ for $\mathrm{OH}$ is difficult to evaluate without direct measurements of $\mathrm{H}_{2} \mathrm{O}, \mathrm{FeO}$, and $\mathrm{Fe}_{2} \mathrm{O}_{3}$ contents. Therefore, even when reliable solution models eventually become available for hornblendes, direct determination of $\mathrm{H}_{2} \mathrm{O}$ will still be necessary to document the presence of oxygen in the hydroxyl site if hornblende is to be used for precise calculations of $\mathrm{H}_{2} \mathrm{O}$ and hydroxyl-amphibole activities.

\section{Implications for hornblende thermobarometry}

Hammarstrom and Zen (1986) proposed an empirically derived barometer involving the Al content of hornblende solid solutions, which has recently become widely used in studies of granitic rocks (e.g., Hollister et al. 1987; Ague and Brimhall 1988; Anderson 1988; Barton et al. 1988). Hollister et al. (1987) empirically recalibrated this barometer based on additional comparisons with other field-based barometers. Johnson and Rutherford (1989) and Rutter et al. (1989) measured the pressure dependence of the $\mathrm{Al}$ content in hornblendes with experimental calibrations, which yield somewhat different pressures than the empirically based equations of Hammarstrom and Zen (1986) and of Hollister et al. (1987). Blundy and Holland (1990) sharply criticize the hornblende barometer suggesting that the emperical correlations between total aluminum in igneous hornblende and pressure may instead reflect variations in granitoid solidus temperatures with pressure. Because none of the above calibrations of the "hornblende barometer" are thermodynamically based, the possible effects of variable ferric iron and/or oxy-substitutions in hornblendes for this barometer are difficult to evaluate. If the serious shortcomings of the hornblende barometer (e.g., Blundy and Holland 1990) can be overcome, the levels of $\mathrm{Fe}^{3+}$ $\mathrm{Fe}^{2+}$ and $\mathrm{O} / \mathrm{OH}$ should be estimated or measured in the natural and synthetic hornblendes on which the barometers are based so that variations in these substitutions can be incorporated in the barometric calibrations. Hornblende barometry is related to the tschermakite exchange, which has been approximated by the total aluminum in hornblende (Hollister et al. 1987). As a firstorder approximation, ferric iron could be added to total aluminum or tetrahedral $\mathrm{Al}$ alone could be used, assuming that ferri-tschermakite would have the same effect as tschermakite. In addition, the effects of variable $P_{\mathrm{H}_{2} \mathrm{O}}$ and of solid solutions in the coexisting minerals (especially biotite and K-feldspar) should be explicitly considered for this barometer. Hornblende barometry needs to be reevaluated using a specific solid-solid reaction while including complete chemical analyses of participating phases and realistic mixing models for hornblendes (and biotites or other hydrous phases if used 
in such calculations). These will not be easy tasks to accomplish.

Graham and Powell (1984), Nabelek and Lindsley (1985), Kohn and Spear (1989, 1990) and Blundy and Holland (1990) evaluated various other hornblendebearing equilibria as potential thermometers and/or barometers. These empirical calibrations yield reasonable apparent temperatures and pressures over restricted $P-$ $T$ ranges of application. However, in none of the hornblende thermobarometers was the effect of the "hidden" substitutions involving $\mathrm{Fe}^{3+} / \mathrm{Fe}^{2+}$ and $\mathrm{O} / \mathrm{OH}$ evaluated in hornblende (and biotite). In addition to the serious difficulties currently engendered by inadequate solution models, any thermobarometry involving complex hydrox$y$-bearing silicates, such as hornblende and biotite, cannot be viewed as fully quantitative until such substitutions are measured and their effects evaluated.

Acknowledgments. This paper was improved by internal reviews of A Afifi, RJ Arculus, AH Francis, AN Halliday, K Mezger and DR Peacor, as well as the external reviews of ED Ghent and FS Spear. The authors are grateful to WP Nash for assistance in the laboratory and to CE Henderson for his maintenance of the electron microprobe. This research was sponsored by a Turner research grant from the University of Michigan to MAC, and NSF grants 84-08169 and 88-05083 to EJE.

\section{References}

Afifi AM, Essene EJ (1988) Minfile: a microcomputer program for storage and manipulation of chemical data on minerals. Am Mineral 73:446-448

Ague JJ, Brimhall GH (1988) Magmatic arc asymmetry and distribution of anomalous plutonic belts in the batholiths of California: effects of assimilation, crustal thickness, and depth of crystallization. Geol Soc Am Bull 100:917-927

Anderson JL (1988) Core complexes of the Mojave-Sonoran Desert: conditions of plutonism, mylonitization and decompression. In: Ernst WG (ed) Metamorphism and crustal evolution of the Western United States. (Rubey Vol VII) Prentice-Hall, Edgewood Cliffs, NJ : 502-525

Barton MD, Battles DA, Debout GE, Capo RC, Christensen JW, Davis SR, Hanson RB, Michelsen CJ, Trim HE (1988) Mesozoic contact metamorphism in the western United States. In: Ernst EG (ed) Metamorphism and Crustal Evolution of the Western United States, Rubey Vol VII, Prentice-Hall, Edgewood Cliffs, N.J., pp 110-178

Bigeleisen J, Perlman ML, Prosser HC (1952) Conversion of hydrogenic materials to hydrogen for isotopic analysis. Anal Chem $24: 1356-1357$

Blundy JD, Holland TJB (1990) Calcic amphibole equilibria and a new amphibole-plagioclase geothermometer. Contrib Mineral Petrol 104:208-224

Bohlen SR, Peacor DR, Essene EJ (1980) Crystal chemistry of a metamorphic biotite and its significance in water barometry. Am Mineral 65:55-62

Clowe CA, Popp RK, Fritz SJ (1988) Experimental investigation of the effect of oxygen fugacity on ferric-ferrous ratios and unit-cell parameters four natural clinoamphiboles. Am Mineral $73: 487-499$

Craig H (1961) Standard for reporting concentrations of deuterium and oxygen-18 in natural waters. Science 133:1833-1834

Cosca MA, Sutter JF, Essene EJ (1991) Cooling and inferred uplift/ erosion history of the Grenville Orogen, Ontario: constraints from ${ }^{40} \mathrm{Ar} /{ }^{39} \mathrm{Ar}$ thermochronology. Tectonics (in press)
Deer WA, Howie RA, Zussman J (1963) Rock-forming minerals. (Vol 2) Green and Co. Ltd, London

Edwards RL, Essene EJ (1988) Pressure, temperature and C-O-H fluid activities across the amphibolite-granulite transition, Northwest Adirondack Mountains, New York. J Pctrol 29:3972

Essene EJ (1989) The current status of thermobarometry in metamorphic rocks. In: Daly JS, Cliff R, Yardley BWD (eds) Evolution of metamorphic belts. Geol Soc Spec Pap 43, pp 1-41

Fairbairn HW (1951) A cooperative investigation of precision and accuracy in chemical, spectrochemical and modal analysis of silicate rocks. US Geol Surv Bull 980

Friedman I (1953) Deuterium content of natural water and other substances. Geochim Cosmochim Acta 4:89-103

Ghent ED (1988) Tremolite and $\mathrm{H}_{2} \mathrm{O}$ activity attending metamorphism of hornblende-plagioclasc-garnct assemblages. Contrib Mineral Petrol 98:163-168

Graham CM, Powell R (1984) A garnet-hornblende geothermometer: calibration, testing, and application to the Pelona schist, southern California. J Metamorphic Geol 2:13-31

Hammarstrom JM, Zen E-an (1986) Aluminum in hornblende: an empirical igneous geobarometer. Am Mineral 64:953-965

Hawthorne FC (1983) The crystal chemistry of the amphiboles. Can Mineral 21:173-480

Hollister LS, Grissom GC, Peters EK, Stowell HH, Sisson VB (1987) Confirmation of the empirical correlation of $\mathrm{Al}$ in hornblende with products of solidification in calc-alkaline plutons. Am Mineral $72: 231-239$

Johnson MC, Rutherford MJ (1989) Experimental calibration of the aluminum-in-hornblende geobarometer with application to Long Valley caldera (California) volcanic rocks. Geology $17: 837-841$

Kohn MJ, Spear FS (1990) Two new geobarometers for garnet amphibolites, with applications to southeastern Vcrmont. Am Mincral 75:89-96

Kohn MJ, Spear FS (1989) Empirical calibration of geobarometers for the assemblage garnet + hornblende + plagioclase + quartz. Am Mineral 74:77-84

Lamb WM, Valley JW (1988) Granulite facies amphibole and biotite equilibria, and calculated peak-metamorphic water activities. Contrib Mineral Petrol 100:349-360

Leake BE (1968) A catalog of analyzed calcifcrous and subcalciferous amphiboles together with their nomenclature and associated minerals. Geol Soc Am Spec Pap 98

Leake BE (1978) Nomenclature of amphiboles. Am Mineral $63: 1023-1052$

Nabelek CR, Lindsley DH (1985) Tetrahedral Al in amphibole - a potential thermometer for some mafic rocks (abstract). Geol Soc Am Abstr Prog 17:673

Penfield SL (1894) On some methods for the determination of water. Am J Sci 48:30-37

Phillips GN (1980) Water activity changes across an amphibolitcgranulite facies transition, Broken Hill, Australia. Contrib Mineral Petrol 75:377-386

Popp RK, Phillips MW, Harrell JA (1990) Accommodation of $\mathrm{Fe}^{3+}$ in natural, $\mathrm{Fe}^{3+}$-rich, calcic and subcalcic amphiboles: Fvidence from published chemical analyses. Am Mineral 75:163-169

Powell R (1975) Thermodynamics of coexisting cummingtonitehornblende pairs. Contrib Mineral Petrol $51: 29-37$

Robinson P, Spcar FS, Schumacher JC, Laird J, Klein C, Evans BW, Doolan BL (1982) Phase relations of metamorphic amphiboles: natural occurrence and theory. In: Veblen DR, Ribbe PH (eds) Amphiboles: Petrology and expcrimental phase relations. (Revicws in Mineralogy 9B) Mineral Soc Am, Washington, D.C., pp 1-227

Rutter MJ, Van der Laan SR, Wyllie PJ (1989) Experimental data for a proposed empirical igncous gcobarometer: aluminum in hornblende at $10 \mathrm{kbar}$ pressure. Geology 17:897-900

Shapiro L, Brannock WW (1956) Rapid analysis of silicate rocks. US Geol Surv Bull 1036C 
Spear FS (1982) Phase equilibria of amphibolites from the Post Pond volcanics, Mt. Cube Quadrangle, Vermont. J Petrol $23: 383-426$

Stout J (1972) Phase petrology and mineral chemistry of coexisting amphiboles from Telemark, Norway. J Petrol 13:99-145

Valley JW, Bohlen SR, Essene EJ, Lamb WM (1990) Metamorphism in the Adirondacks: II: The role of fluids. J Petrol $31: 555-596$

Valley JW, McLelland J, Essene EJ, Lamb WM (1983) Metamor- phic fluids in the deep crust: evidence from the Adirondacks. Nature $301: 226-228$

Valley JW, Peterson EU, Essene EJ, Bowman JR (1982) Fluorphlogopite and fluortremolite in Adirondack marbles and calculated C-O-H-F fluid compositions. Am Mineral 67:545-557

Wilson AD (1955) A new method for the determination of ferrous iron in rocks and minerals. Bull Geol Soc Great Britain 9:56-58

Editorial responsibility: I.S.E. Casmichael 